\begin{tabular}{|l|l|l|l|}
\hline Verh. Internat. Verein. Limnol. & 27 & $1-2$ & Stuttgart, April 2000 \\
\hline
\end{tabular}

\title{
Constructed wetlands for treatment of mine tailings at Tara Mines, Ireland
}

\author{
Aisling D. O’Sullivan, Declan A. Murray and Marinus L. Otte
}

\begin{abstract}
Natural and constructed wetlands can filter pollutants from water. Recently this property has been exploited in utilising wetlands for passive water treatment. Using relatively concentrated waste, wetlands have been shown to be effective in retaining in excess of $90 \%$ metals (MAY et al. 1993) and over $70 \%$ sulphate (WINTER \& KICKUTH 1989). This approach to water quality improvement is more favourable than traditional treatment methods requiring intensive chemical and labour inputs. Experimental wetlands have been constructed on site at Tara Mines, County Meath, Ireland to facilitate a research project investigating the capacity of filter systems in retaining sulphate and metals from mine tailings water. It is expected that such systems, based on natural processes, will be efficient yet require little maintenance and will, therefore, be economically attractive.

Optimum plant growth and substrate permeability for the wetlands at Tara Mines were achieved using a substrate consisting of 25\% Spent Mushroom Compost (SMC) and a $75 \%$ fine grit. This substrate provides a rich source of Dissimilatory Sulphate Reduction (DSR) bacteria such as Desulfovibrio and other sulphur metabolites, which mediate the sulphate reduction reactions (BECKETT et al. 1997). These biological and chemical processes involve the reduction of sulphate under anaerobic conditions to sulphide. The resulting sulphides subsequently react with dissolved metals rendering insoluble precipitates. Cattails (Typha latifolia) and the common reed (Phragmites australis) amongst other aquatic plants are frequently employed for water treatment (KaDLEC 1996). Therefore, Typha latifolia, Phragmites australis and Glyceria fluitans were planted at a ratio of $4: 9: 4$ per $\mathrm{m}^{2}$, respectively, in each wetland filter at Tara Mines.

Using programs such as WATEQ (DVORAK et al. 1992), mathematical modelling will figure prominently in predicting the fate of the ions (or compounds) and life span of these wetlands with respect to the retention of sulphate and heavy metals. Toxic-
\end{abstract}

ity within the wetland habitat is predicted using the ratio of Simultaneously Extracted Metal (SEM) to Acid-Volatile Sulphide (AVS) as derived from Allen et al. 1993.

The presence of microbial activity (sulphate reducing bacteria) was determined qualitatively as indicated by the production of $\mathrm{H}_{2} \mathrm{~S}$ gas. A study identifying and characterising the specific microbes and their role(s) within the wetlands is being initiated. Conductivity output readings were consistently lower in both wetlands and by up to $31 \%$ compared to input measurements. At these levels, total ionic strength is linear to conductivity, and therefore, these values also account for up to a $31 \%$ reduction in ionic concentration. Results indicated that $\mathrm{pH}$ is well buffered in the wetlands around 7.6. Temperatures varied between $3{ }^{\circ} \mathrm{C}$ in December and $25^{\circ} \mathrm{C}$ in July. Preliminary results indicate that the wetlands are functioning in terms of reduction in ion content of surface water. Plant growth is prolific and there is already a diverse volunteer invertebrate community indicating a healthy ecosystem within the wetland filters. Flow rates for water passing through the wetlands are presently set at $300 \mathrm{~mL} / \mathrm{min}$, which is the recommended flow rate for maximum retention of metals and sulphates for an equal area of filtration (Crites 1994, Stalker 1996).

\section{Acknowledgements}

We acknowledge the support of Outokumpu Zinc (Tara Mines) Ltd. and Forbairt (Applied Research Grants).

\section{References}

Allen, H. E., Fu, G. \& DenG, B., 1992: Analysis of acid-volatile sulphide (AVS) and simultaneously extracted metals (SEM) for the estimation of potential toxicity in aquatic sediments. - Environ. Toxicol. Chem. 12: 1441-1453.

Beckett, P., Willianen, S., Vivyurka, A. \& Courtin, G., 1997: Establishment of deep-water aquatic plants in permanently flooded pyritic uranium tailings: a field test. - Presented at the 4 th International Conference on acid rock 
drainage, Vancouver, BC, Canada

CRITES, R.W., 1994: Design criteria and practice constructed wetlands. - Water Sci. Technol. 29(4): 1-6.

Dvorak, D. H., Hedin, R. S., Edenborn, H. M. \& McIntiRe, P. M., 1992: Treatment of metal contaminated water using bacterial sulphate reduction: results of pilot-scale reactors. Biotechnol. Bioeng. 40: 609-616.

KADLEC, R. H., 1996: Wetland design: surface flow wetlands: Plants and Planting. - In: Kadlec, R. H. \& KNIGHT, R. L. (eds): Treatment Wetlands: 633-634. - Lewis Publishers, CRC Press, Florida.

MAY, X., LiU, X. \& WANG, R., 1993: China's wetlands and agro-ecological engineering. - Ecol. Eng. 2: 291-301.

STALKER, J., 1996: The utilisation of bacterial sulphate reduction for the in-situ abatement of acid mine drainage using waste organic matter. - M.Sc. Dissertation, Pennsylvania State University, Pennsylvania.

WINTER, M. \& KICKUTH, R., 1989: Elimination of sulphur compounds from wastewater by the root zone process. 1 : Performance of a large-scale purification plant at a textile finishing industry. 11: Mode of formation of sulphur deposits. - Water Res. 23: 535-546 (1) \& 547-560 (11).

Authors' addresses

A. D. O'Sullivan, Department of Botany, University College Dublin, Belfield, Dublin 4, Ireland.

D. A. Murray, Department of Zoology, University College Dublin, Belfield, Dublin 4, Ireland. M. L. OtTE, 